\title{
Implementasi E-Commerce Berbasis Web pada Toko Denia Donuts Menggunakan Metode Prototype
}

Fenando Fenando

fenando uin@radenfatah.ac.id

\section{Universitas Islam Negeri Raden Fatah Palembang - Indonesia}

Diterima: 17 Sep 2020 | Direvisi: 04 Okt - 12 Nov 2020

Disetujui: 29 Nov 2020 | Dipublikasi: 28 Des 2020

Program Studi Sistem Informasi, Fakultas Sains dan Teknologi,

Universitas Islam Negeri Raden Fatah Palembang, Indonesia

ABSTRACT

The development of the internet and the implementation of technology that makes it easier for users to increasingly influence the business sector. Business people are starting to take advantage of the internet and technology to run their business or so-called E-Commerce. Denia Donuts Shop is an online shop that sells donuts in South Sumatera. The problems that occur, even though this store has marketed its products online, shop owners still use social media only in the process of transactions with consumers. This becomes very difficult when consumers want to make a purchase, consumers must send messages according to the format determined by the shop's owner, this method is made very difficult for consumers every time they make a purchase. On the other hand, the shop owner also finds it difficult to find product information, stock information, find out which consumers have bought during a certain period, and sales reports that are still recorded in a book. This article aims to build E-Commerce at Denia Donuts Shop that can help in marketing products widely and facilitate the process of transactions carried out by consumers. The system development method used is the prototype method. This research has resulted in an E-Commerce system that has been tested using the black box testing method and has been implemented in accordance with user requirements specifications.

Keywords: E-Commerce, Web-based, Prototype

\section{ABSTRAK}

Perkembangan internet dan penerapan teknologi yang memudahkan pengguna semakin mempengaruhi sektor bisnis. Para pebisnis mulai memanfaatkan internet dan teknologi untuk menjalankan bisnis mereka atau biasa disebut E-Commerce (perniagaan secara elektronik). Toko Denia Donuts merupakan toko online yang menjual donat yang berada di Sumatera Selatan. Permasalahan yang terjadi, walaupun toko ini sudah secara online memasarkan produknya, namun pemilik toko masih menggunakan media sosial saja dalam proses transaksi dengan konsumen. Hal ini menjadi sangat sulit ketika konsumen ingin melakukan pembelian maka konsumen harus mengirimkan pesan sesuai format yang telah ditentukan oleh pihak toko, cara ini tentunya sangat menyulitkan konsumen setiap kali melakukan pembelian. Di sisi lain, pemilik toko juga kesulitan dalam mencari informasi produk, informasi stok barang, mengetahui konsumen yang telah membeli selama periode tertentu, dan laporan penjualan yang masih dicatat di sebuah buku. Artikel ini bertujuan untuk membangun E-Commerce pada toko Denia Donuts yang dapat membantu dalam memasarkan produk secara luas dan memudahkan dalam proses transaksi yang dilakukan oleh konsumen. Metode pengembangan sistem yang digunakan adalah metode prototype. Dari penelitian ini menghasilkan sistem ECommerce yang telah diujicobakan dengan menggunakan metode black box testing dan telah diimplementasikan sesuai dengan spesifikasi kebutuhan pengguna.

Kata Kunci: E-Commerce, Berbasis Web, Prototype 


\section{PENDAHULUAN}

Perkembangan internet dan penerapan teknologi yang memudahkan pengguna (Gunawan \& Fenando, 2018) semakin mempengaruhi sektor bisnis. Melalui internet, para pebisnis dapat menjangkau secara luas konsumen baru untuk meningkatkan penjualan bisnis mereka. Penyebaran penggunaan internet secara luas, menjadikan internet banyak dimanfaatkan oleh masyarakat, kapan saja dan dimana saja selama masih terhubung ke suatu jaringan internet. Kesempatan untuk mendapatkan konsumen baru melalui pemanfaatan internet akan sangat menjanjikan. Penggunaan teknologi dapat membantu dalam memberikan layanan yang baik bagi konsumen (Pranita, Zulfikar, \& Gunawan, 2019). Para pebisnis mulai memanfaatkan internet dan teknologi untuk menjalankan bisnis mereka atau biasa disebut E-Commerce (perniagaan secara elektronik). Aktivitas E-Commerce, merupakan usaha seseorang atau individu dalam menjalankan bisnisnya dengan memanfaatkan suatu media atau piranti secara online (Suryono \& Java Creativity, 2014). Dengan E-Commerce, konsumen yang ingin membeli barang atau jasa pada suatu toko online dengan mudah dapat melihat barang atau jasa yang ditawarkan kepada mereka melalui halaman situs yang telah disediakan.

Salah satu pemanfaatan teknologi untuk menunjang dalam penerapan E-Commerce, yaitu dengan menyediakan website sebagai toko online. Berbagai kemudahan dalam membuat website, seringkali digunakan dengan memanfaatkan open source framework. Di dalam artikel ini digunakan framework Codelgniter untuk menghasilkan sebuah toko online. Framework CodeIgniter dipilih karena bersifat open source, sederhana bagi pengembang, ringan tetapi memiliki fitur yang lengkap, dan memiliki dokumentasi yang lengkap (Destiningrum \& Adrian, 2017) sehingga dapat mempercepat pembuatan toko online ini.

Beberapa penelitian terdahulu yang berkaitan dengan pentingnya E-Commerce untuk menunjang bisnis, seperti pada penelitian (Susilo, Kurniati, \& Kasmawi, 2018) membuat toko online aksesoris komputer dan laptop untuk meningkatkan penjualan toko, penelitian (Haerulah \& Ismiyatih, 2017) membuat toko online souvenir pernikahan, penelitian (Kosasi, 2015) membuat toko online untuk pemasaran produk pembuatan kue, penelitian (Halim \& Aziz, 2018) yang memanfaatkan E-Commerce dengan membuat aplikasi layanan E-Commerce tempat pembelian oleh-oleh wisata Anyer. Penelitian (Wahyuni \& Puadah, 2019) yang bertujuan untuk membangun aplikasi penjualan online untuk memasarkan usaha kecil penghasil produk dengan teknik rajutan dengan menggunakan metode Rational Unified Proccess (RUP). Pada penelitian yang dilakukan (Nuraeni \& Astuti, 2019), dilakukan rancang bangun E-Commerce untuk meningkatkan penjualan toko Batik Pekalongan (R3N Batik), dalam membangun E-Commerce ini digunakan pendekatan Waterfall sebagai metode pengembangan sistem dalam membangun perangkat lunak tersebut.

Artikel ini bertujuan untuk membangun E-Commerce pada toko Denia Donuts yang dapat membantu dalam memasarkan produk secara luas dan memudahkan dalam proses transaksi yang dilakukan oleh konsumen. Toko Denia Donuts merupakan sebuah toko online yang menjual donat yang berbentuk huruf, yang menjadikan produsen donat berbentuk huruf yang pertama kali ada di Sumatera Selatan. Toko Denia Donuts berlokasi di Komplek Azhar, Jl. Melaburi No. 7, Talang Buluh, Kabupaten Banyuasin, Sumatera Selatan. Saat ini, toko Denia Donuts masih menggunakan media sosial media seperti Instagram, Whatsapp, dan Line untuk memasarkan produk mereka. Untuk proses pemesanan, konsumen bisa menghubungi akun sosial media toko Denia Donuts disertakan dengan format pesanan yang telah ditentukan. Permasalahan yang ada sekarang adalah cukup sulitnya melakukan transaksi pembelian, dimana konsumen harus memesan sesuai format pemesanan yang datanya cukup banyak setiap kali 
membeli produk. Sedangkan bagi pemilik, sulitnya mencari informasi produk yang dibutuhkan, tidak adanya informasi stok produk, sulit untuk mengumpulkan data konsumen yang telah membeli produk, dan laporan penjualan yang masih dicatat di buku besar lalu disimpan oleh pemilik toko di dalam lemari.

Metode pengembangan sistem yang digunakan dalam penelitian ini adalah metode Prototype. Menurut (Pressman, 2012), dengan menggunakan prototype maka pengguna dapat dengan mudah mendapat gambaran dari sistem yang sebenarnya. Prototype bukanlah bentuk lengkap sistem, akan tetapi tidak akan jauh berbeda dengan sistem yang akan dibuat. Prototype mudah untuk dievaluasi ketika terdapat perbaikan pada sistem.

\section{METODOLOGI PENELITIAN}

\section{Metode Pengembangan Sistem}

Pada penelitian ini digunakan metode prototype dalam membangun perangkat lunak (E-Commerce) untuk meningkatkan dan memudahkan konsumen toko Denia Donuts dalam bertransaksi. Menurut (Pressman, 2012), memiliki beberapa tahapan pengembangan sistem yang dimulai dari proses komunikasi dengan pengguna. Tahapan pada metode prototype secara lengkap dapat dilihat pada Gambar 1.

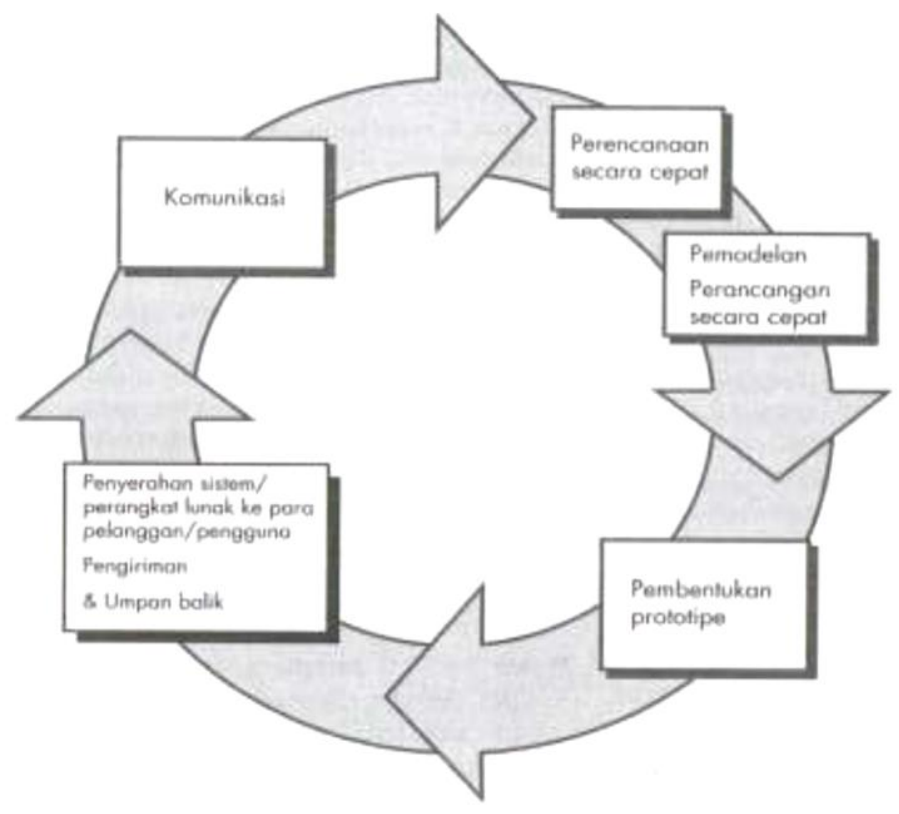

Gambar 1. Tahapan pada Metode Prototype

Pada Gambar 1 merupakan alur pengembangan sistem, berikut ini penjelasan dari tahapan-tahapan yang terdapat pada metode prototype:

1) Komunikasi awal dilakukan dengan melibatkan pemilik toko Denia Donuts. Pada tahap komunikasi awal digunakan untuk mendefinisikan sistem untuk menyediakan prototype awal kepada pemilik toko Denia Donuts. Pertemuan dengan pemilik toko Denia Donuts akan sering dilakukan setiap kali prototype yang baru selesai dikerjakan. Hal ini terus dilakukan selama penyelesaian sistem E-Commerce agar kebutuhan pengguna dapat secepat mungkin diidentifikasi. Setiap komunikasi dan penyajian prototype yang baru merupakan langkah penting untuk menyelesaikan sistem E-Commerce ini sesuai dengan kebutuhan pengguna.

2) Pada tahap perencanaan ini, akan disusun rencana awal dalam pembuatan prototype awal yang digunakan sebagai gambaran awal bagi pemilik toko Denia 
Donuts. Prototype awal ini masih belum lengkap, akan tetapi dari prototype awal ini dapat sebanyak mungkin ditemukan kebutuhan pengguna. Tahapan iterasi selanjuntnya pada tahap ini merupakan perencanaan singkat untuk menghasilkan prototype yang sesuai kebutuhan pengguna.

3) Pada tahap ini akan menyajikan pemodelan alur dan desain sistem E-Commerce yang dibuat secara singkat. Fokus dari tahap pemodelan ini menyajikan gambaran alur dan perangkat lunak yang dapat dilihat oleh pemilik toko Denia Donuts.

4) Pembentukan prototype awal akan dilakukan secara cepat yang dapat digunakan untuk memberikan gambaran awal dari sistem E-Commerce. Prototype awal pastinya belum memiliki fungsi yang sempurna dan belum lengkap fitur yang disediakan. Prototype pada iterasi selanjutnya akan semakin baik dan sesuai dengan kebutuhan dari pemilik toko Denia Donuts dan konsumennya.

5) Penyerahan prototype akan dilakukan untuk mendapatkan umpan balik dari pemilik toko Denia Donuts. Evaluasi pada prototype akan terus dilakukan pada setiap iterasi dan selalu melibatkan pemilik toko Denia Donuts.

\section{Metode Pengumpulan Data}

Dalam penelitian ini digunakan beberapa cara untuk mengumpulkan data-data dalam penelitian ini. Adapun cara-cara yang digunakan, sebagai berikut:

1) Wawancara

Pada penelitian ini digunakan wawancara untuk memperdalam dan mengumpulkan data demi menunjang penelitian ini. Teknik wawancara ini merupakan teknik untuk mendapatkan informasi dengan melalui tanya-jawab sehingga dapat dikonstruksikan makna di dalam bahasan suatu topik (Sugiyono, 2019). Dalam hal ini, tanya-jawab dilakukan kepada pemilik toko Denia Donuts terkait proses bisnis yang terjadi selama ini. Kemudian seluruh informasi dikumpulkan sebagai bahan masukan dalam membangun E-Commerce.

2) Studi Dokumentasi

Studi dokumentasi digunakan untuk mengumpulkan data dengan menghimpun dan dokumen tertulis (Nilamsari, 2014), baik gambar, catatan tertulis maupun elektronik. Hal ini dilakukan untuk memperdalam pemahaman terhadap proses bisnis, kebiasaan konsumen, dan penyusunan fitur pada sistem E-Commerce.

3) Studi Kepustakaan

Studi kepustakaan merupakan teknik pengumpulan data dengan cara mempelajari literatur, modul, pedoman/panduan, artikel jurnal, media referensi lainnya yang berkaitan dengan permasalahan yang dibahas (Arif, Wanda, \& Masudi, 2013). Dalam hal ini, dibutuhkan artikel-artikel jurnal serta buku praktis sebagai petunjuk dalam pembuatan E-Commerce dan pembuatan artikel ini.

\section{HASIL DAN PEMBAHASAN}

\section{Komunikasi (Communication)}

Komunikasi dilakukan untuk mendapatkan gambaran atau alur sistem dalam mengembangkan dan membangun E-Commerce menjadi lebih baik lagi. Oleh karena itu diperlukan komunikasi yang baik dengan pemilik, dan karyawan di toko Denia Donuts.

Dari hasil wawancara dengan pemilik toko Denia Donuts. Diketahui bahwa saat ini media pemasaran toko ini hanya menggunakan media sosial media seperti Instagram, Whatsapp, dan Line untuk memasarkan produk mereka. Untuk proses pemesanan, konsumen bisa menghubungi akun sosial media toko Denia Donuts disertakan dengan format pesanan yang telah ditentukan. Permasalahan yang ada sekarang adalah cukup 
sulitnya melakukan transaksi pembelian, dimana konsumen harus memesan sesuai format pemesanan yang datanya cukup banyak setiap kali membeli produk. Sedangkan bagi pemilik, sulitnya mencari informasi produk yang dibutuhkan, tidak adanya informasi stok produk, sulit untuk mengumpulkan data konsumen yang telah membeli produk, dan laporan pendapatan yang masih dicatat di buku besar lalu disimpan oleh pemilik toko di dalam lemari. Alur sistem yang sedang berjalan pada saat ini dapat dilihat pada Gambar 2.

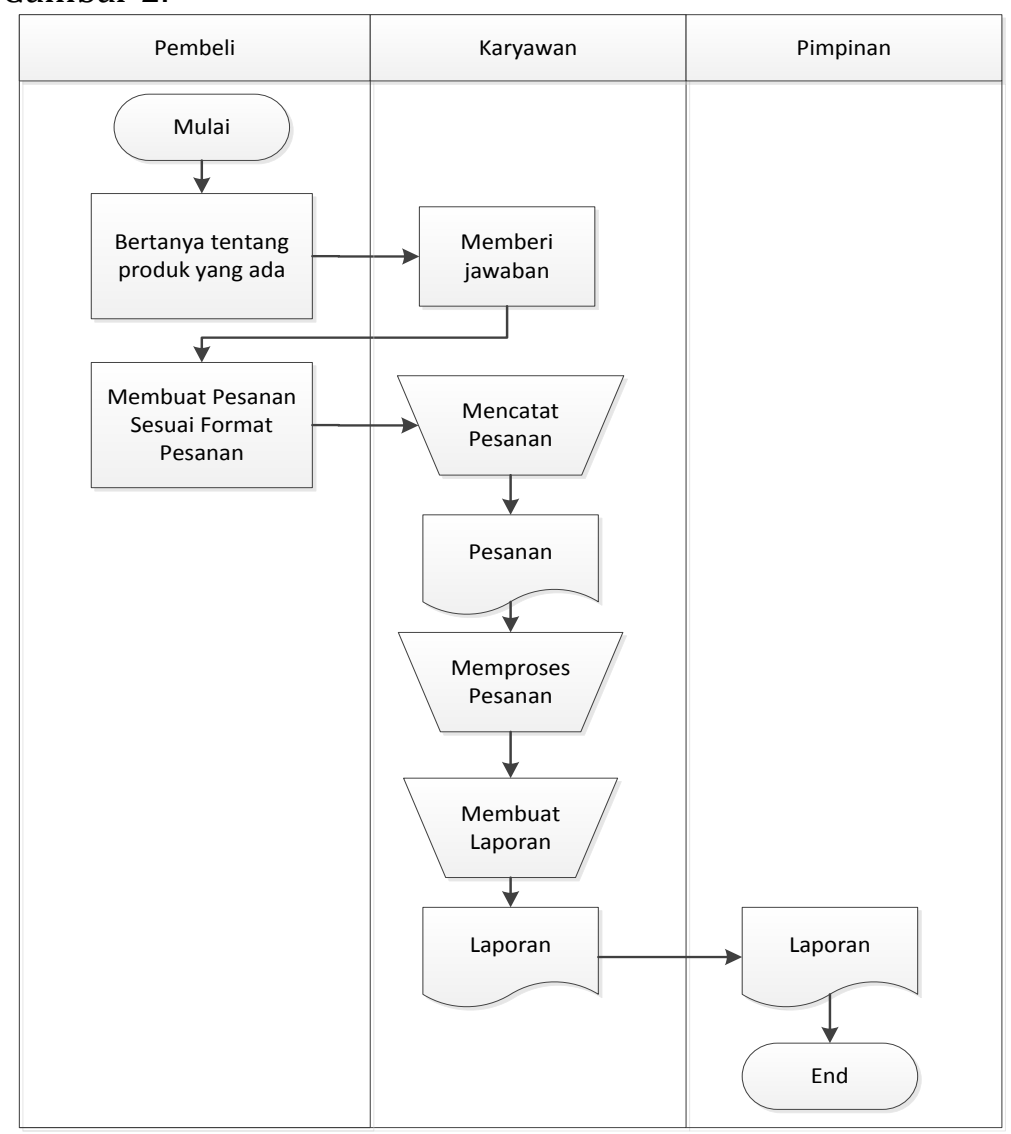

Gambar 2. Alur Sistem yang Sedang Berjalan

\section{Perencanaan Secara Cepat}

Dalam membangun sebuah sistem yang baik, diperlukanlah penjadwalan pembangunan sistem, hal ini diperuntukkan kedepannya dalam melakukan proses pengembangan ataupun pembangunan sebuah sistem nantinya dapat berjalan dengan baik sesuai dengan jadwal yang telah ditetapkan. Dalam Penelitian ini, hal yang pertama dilakukan adalah survei ke lokasi, tahap selanjutnya membuatan surat izin penelitian, tujuan penelitian, dokumen yang dibutuhkan, arsip penjualan, dan proses bisnis dari toko yang telah berjalan saat ini.

\section{Pemodelan Secara Cepat}

\section{1) Use Case Diagram}

Pada tahap ini setiap proses yang ada dimodelkan sesuai dengan kebutuhan. Berikut ini merupakan use case diagram yang diusulkan pada pembuatan E-Commerce di toko Denia Donuts. Dapat dilihat pada Gambar 3. 


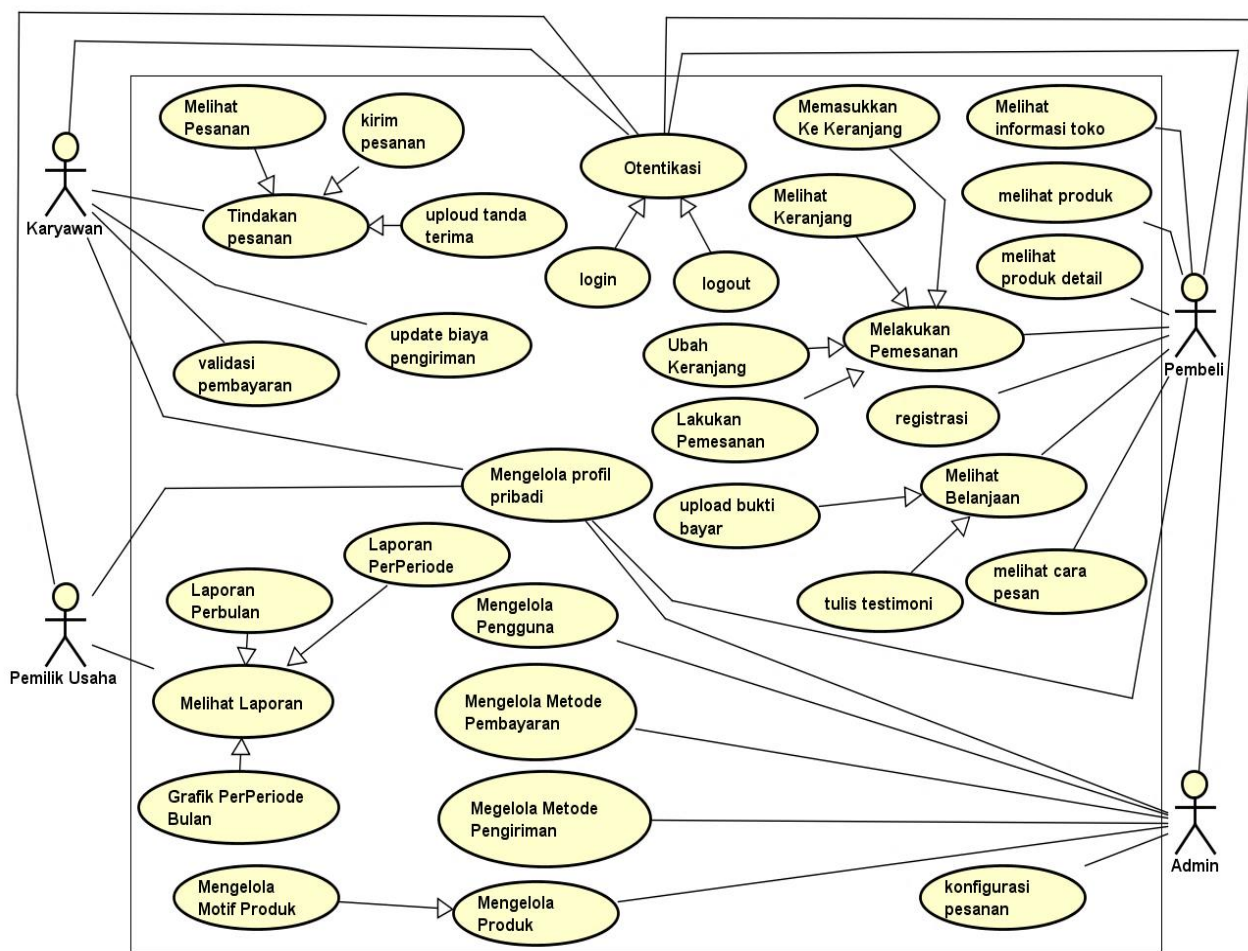

Gambar 3. Use case Diagram Sistem yang diusulkan

\section{2) Activity Diagram}

Pada penelitian ini, digambarkan 4 (empat) activity diagram, sebagai berikut:

- Activity Diagram Admin

- Activity Diagram Karyawan

- Activity Diagram Pimpinan

- Activity Diagram Pembeli/pelanggan

Berikut ini merupakan activity diagram admin yang telah dibuat. Dapat dilihat pada Gambar 4.

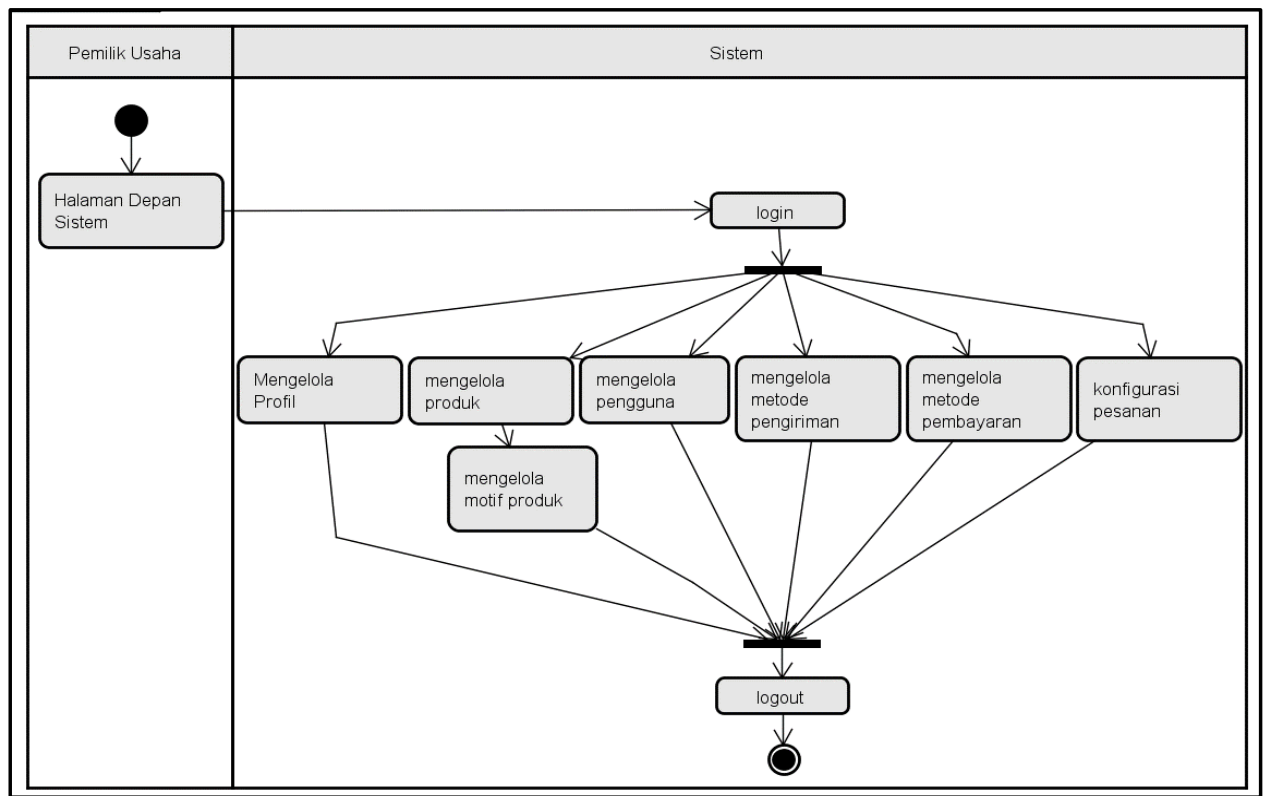

Gambar 4. Activity Diagram Admin 


\section{Konstruksi (Pembentukan Prototype)}

Pada tahap awal, akan disediakan seluruh rancangan antarmuka pengguna yang ada pada sistem E-Commerce ini. Perancangan antarmuka pengguna (user interface) dilakukan dengan tujuan untuk mempermudah pengguna dalam menggunakan sistem berbasis web (Gunawan, Ramadhan, \& Indrawan, 2013). Rancangan antarmuka yang dibuat pada sistem E-Commerce, sebagai berikut:

1) Rancangan Antarmuka Home,

2) Rancangan Antarmuka Registrasi,

3) Rancangan Antarmuka Informasi Produk,

4) Rancangan Antarmuka Detail Produk,

5) Rancangan Antarmuka Keranjang Belanja Sementara,

6) Rancangan Antarmuka Keranjang Belanja Proses,

7) Rancangan Antarmuka Daftar Belanja,

8) Rancangan Antarmuka Profil Pribadi,

9) Rancangan Antarmuka Data Produk,

10) Rancangan Antarmuka Data Pengguna,

11) Rancangan Antarmuka Metode Pengiriman,

12) Rancangan Antarmuka Metode Pembayaran,

13) Rancangan Antarmuka Konfigurasi Pesanan,

14) Rancangan Antarmuka Data Pesanan,

15) Rancangan Antarmuka Data Pesanan dengan Jasa Pengiriman,

16) Rancangan Antarmuka Data Tagihan Pembayaran,

17) Rancangan Antarmuka Laporan Per-bulan,

18) Rancangan Antarmuka Laporan Per-periode,

19) Rancangan Antarmuka Grafik Penjualan,

20) Rancangan Antarmuka Cetak Invoice,

21) Rancangan Antarmuka Cetak Pesanan,

22) Rancangan Antarmuka Cetak Laporan Per-bulan,

23) Rancangan Antarmuka Cetak Laporan Per-periode.

\section{Implementasi Rancangan Antarmuka}

Pada tahap ini dilakukan implementasi sesuai dengan rancangan antarmuka yang telah direncanakan sebelumnya. Berikut ini sebagian implementasi yang dapat dilihat pada Gambar 5.

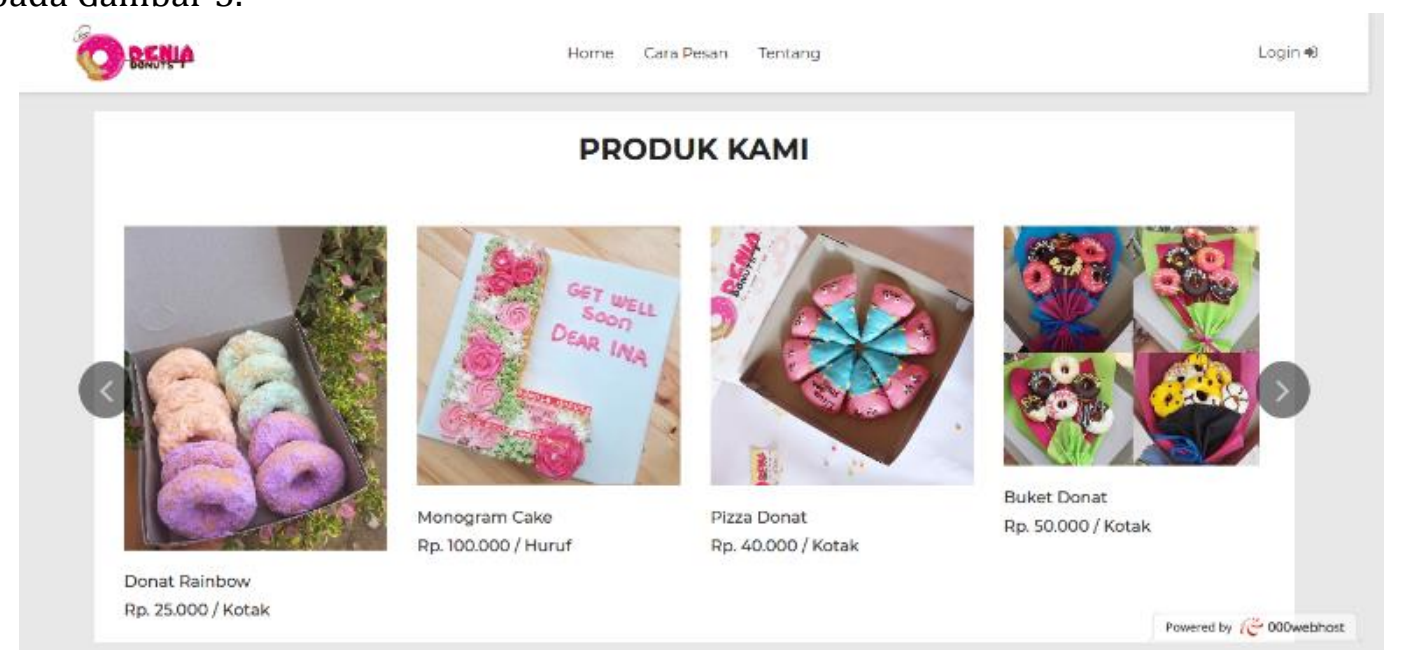

Gambar 5. Implementasi Rancangan Antarmuka Informasi Produk 
Pada halaman detail produk, konsumen dapat melihat variasi produk yang tersedia di toko Denia Donuts. Setiap item produk diberikan keterangan nama, harga, serta satuan dari item produk. Konsumen dapat memesan dan melihat detail dari produk dengan menekan item produk yang ingin dibeli. Dapat dilihat pada Gambar 6.

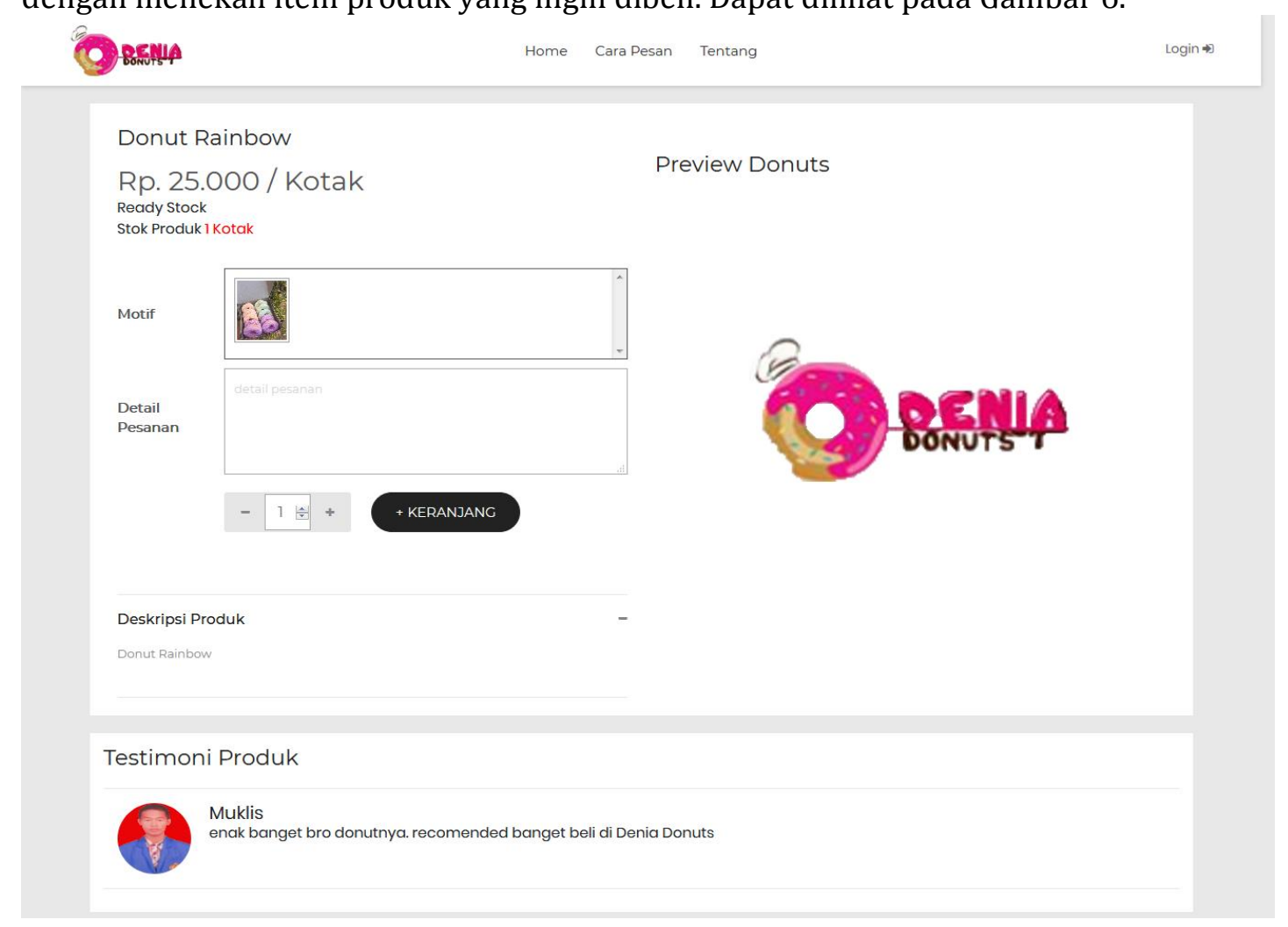

\section{Gambar 6. Implementasi Rancangan Antarmuka Detail Produk}

Pada penelitian ini juga diimplementasi semua rancangan antarmuka yang telah disebutkan sebelumnya. Setiap rancangan antarmuka memiliki kegunaan yang berbeda-beda yang telah disesuaikan dengan kebutuhan di toko Denia Donuts.

\section{Penyerahan Sistem \& Umpan balik}

Tahap penyerahan sistem bertujuan untuk mendapatkan umpan balik dari pemilik toko Denia Donuts. Setiap prototype yang baru akan diserahkan ke pemilik toko Denia Donuts untuk mengetahui sudah sejauh mana sistem E-Commerce memenuhi kebutuhan toko Denia Donuts. Dengan menggunakan metode prototype akan mengalami beberapa iterasi sampai sistem E-Commerce sesuai dengan kebutuhan toko Denia Donuts. Apabila sistem E-Commerce ini telah baik dan sesuai dengan kebutuhan toko Denia Donuts, maka akan diserahkan secara penuh kepada pemilik toko Denia Donuts.

\section{Pengujian Sistem E-Commerce}

Pengujian yang dilakukan pada sistem E-Commerce ini dengan menggunakan Black Box Testing. Pengujian ini bertujuan untuk mengetahui apakah fungsi-fungsi, masukan, dan keluaran dari sistem yang dibangun sudah sesuai dengan spesifikasi sistem yang dibutuhkan. Dalam pengujian ini akan dilakukan pengujian oleh 4 (empat) tipe pengguna, yaitu: pengujian sistem oleh pemilik usaha, pengujian sistem oleh karyawan, pengujian sistem oleh pembeli, dan pengujian sistem oleh admin. Berikut ini pengujian 
sistem yang telah dilakukan, diwakilkan dengan menampilkan pengujian yang dilakukan oleh admin, sebagian pengujian dapat dilihat pada Tabel 1.

\section{Tabel 1. Hasil Akhir Pengujian yang Dilakukan oleh Admin}

\begin{tabular}{|c|c|c|c|c|}
\hline No. & $\begin{array}{c}\text { Fungsi yang } \\
\text { diuji }\end{array}$ & Cara pengujian & $\begin{array}{c}\text { Hasil yang } \\
\text { diharapkan }\end{array}$ & $\begin{array}{c}\text { Hasil } \\
\text { Pengujian }\end{array}$ \\
\hline 1. & Proses Login & $\begin{array}{l}\text { Memasukkan } \\
\text { username dan } \\
\text { password }\end{array}$ & $\begin{array}{l}\text { Menampilkan menu } \\
\text { sesuai kategori } \\
\text { pengguna }\end{array}$ & OK \\
\hline 2. & $\begin{array}{l}\text { Proses edit } \\
\text { data pribadi }\end{array}$ & $\begin{array}{l}\text { Ubah nama, tampat } \\
\text { lahir, tanggal lahir, } \\
\text { alamat, nomor } \\
\text { handphone, nomor } \\
\text { Whatsapp, Line, } \\
\text { Instagram, jenis } \\
\text { kelamin dan foto }\end{array}$ & Data pribadi berubah & $\mathrm{OK}$ \\
\hline 3. & $\begin{array}{l}\text { Fungsi edit } \\
\text { password }\end{array}$ & $\begin{array}{l}\text { memasukkan password } \\
\text { lama, password baru } \\
\text { dan pengulangan } \\
\text { password baru }\end{array}$ & $\begin{array}{l}\text { Password untuk login } \\
\text { ke sistem berhasil } \\
\text { berubah }\end{array}$ & $\mathrm{OK}$ \\
\hline 4. & $\begin{array}{l}\text { Proses } \\
\text { tambah data } \\
\text { metode } \\
\text { pengiriman }\end{array}$ & Masukkan nama & $\begin{array}{l}\text { Data metode } \\
\text { pengiriman } \\
\text { bertambah }\end{array}$ & $\mathrm{OK}$ \\
\hline 5. & $\begin{array}{l}\text { Fungsi } \\
\text { hapus data } \\
\text { metode } \\
\text { pengiriman }\end{array}$ & $\begin{array}{l}\text { Pilih tombol hapus di } \\
\text { metode pengiriman } \\
\text { yang akan dihapus }\end{array}$ & $\begin{array}{l}\text { Data metode } \\
\text { pengiriman terhapus }\end{array}$ & $\mathrm{OK}$ \\
\hline 6. & $\begin{array}{l}\text { Proses } \\
\text { tambah data } \\
\text { produk }\end{array}$ & $\begin{array}{l}\text { Masukkan nama, } \\
\text { harga, satuan, stok, } \\
\text { deskripsi, dan gambar } \\
\text { utama produk }\end{array}$ & $\begin{array}{l}\text { Data produk } \\
\text { bertambah }\end{array}$ & $\mathrm{OK}$ \\
\hline 7. & $\begin{array}{l}\text { Fungsi edit } \\
\text { data produk }\end{array}$ & $\begin{array}{l}\text { Ubah nama, harga, } \\
\text { satuan, stok, deskripsi, } \\
\text { dan gambar utama } \\
\text { produk }\end{array}$ & Data produk berubah & $\mathrm{OK}$ \\
\hline 8. & $\begin{array}{l}\text { Fungsi } \\
\text { hapus data } \\
\text { produk }\end{array}$ & $\begin{array}{l}\text { Pilih tombol hapus di } \\
\text { produk yang akan } \\
\text { dihapus }\end{array}$ & $\begin{array}{l}\text { Data produk dan } \\
\text { motif produk } \\
\text { terhapus }\end{array}$ & $\mathrm{OK}$ \\
\hline 9. & $\begin{array}{l}\text { Fungsi } \\
\text { tambah } \\
\text { motif } \\
\text { produk }\end{array}$ & $\begin{array}{l}\text { Pilih gambar motif dari } \\
\text { komputer admin }\end{array}$ & $\begin{array}{l}\text { Data motif produk } \\
\text { bertambah }\end{array}$ & $\mathrm{OK}$ \\
\hline
\end{tabular}


Tabel 1. Lanjutan Hasil Akhir Pengujian yang Dilakukan oleh Admin

\begin{tabular}{|c|c|c|c|c|}
\hline No. & $\begin{array}{l}\text { Fungsi yang } \\
\text { diuji }\end{array}$ & Cara pengujian & $\begin{array}{c}\text { Hasil yang } \\
\text { diharapkan }\end{array}$ & $\begin{array}{c}\text { Hasil } \\
\text { Pengujian }\end{array}$ \\
\hline 10. & $\begin{array}{l}\text { Fungsi } \\
\text { hapus motif } \\
\text { produk }\end{array}$ & $\begin{array}{l}\text { Pilih gambar motif } \\
\text { yang akan dihapus }\end{array}$ & $\begin{array}{l}\text { Data motif produk } \\
\text { terhapus }\end{array}$ & $\mathrm{OK}$ \\
\hline 11. & $\begin{array}{l}\text { Proses } \\
\text { tambah data } \\
\text { pengguna }\end{array}$ & $\begin{array}{l}\text { masukkan email, } \\
\text { password, nama, } \\
\text { tampat lahir, tanggal } \\
\text { lahir, alamat, nomor } \\
\text { handphone, nomor } \\
\text { Whatsapp, Line, } \\
\text { Instagram, jenis } \\
\text { kelamin dan foto }\end{array}$ & $\begin{array}{l}\text { Data pengguna } \\
\text { bertambah }\end{array}$ & $\mathrm{OK}$ \\
\hline 12. & $\begin{array}{l}\text { Fungsi edit } \\
\text { data } \\
\text { pengguna }\end{array}$ & $\begin{array}{l}\text { ubah nama, tampat } \\
\text { lahir, tanggal lahir, } \\
\text { alamat, nomor } \\
\text { handphone, nomor } \\
\text { Whatsapp, Line, } \\
\text { Instagram, jenis } \\
\text { kelamin dan foto }\end{array}$ & $\begin{array}{l}\text { Data pengguna } \\
\text { berubah }\end{array}$ & $\mathrm{OK}$ \\
\hline 13. & $\begin{array}{l}\text { Fungsi } \\
\text { hapus data } \\
\text { pengguna }\end{array}$ & $\begin{array}{l}\text { Pilih tombol hapus di } \\
\text { pengguna yang akan } \\
\text { dihapus }\end{array}$ & $\begin{array}{l}\text { Data pengguna } \\
\text { terhapus }\end{array}$ & $\mathrm{OK}$ \\
\hline 14. & $\begin{array}{l}\text { Proses } \\
\text { tambah data } \\
\text { metode } \\
\text { pembayaran }\end{array}$ & $\begin{array}{l}\text { Masukkan nama } \\
\text { metode pembayaran, } \\
\text { nama bank, dan nomer } \\
\text { rekening bank }\end{array}$ & $\begin{array}{l}\text { Data metode } \\
\text { pembayaran } \\
\text { bertambah }\end{array}$ & $\mathrm{OK}$ \\
\hline 15. & $\begin{array}{l}\text { Fungsi } \\
\text { hapus data } \\
\text { pembayaran }\end{array}$ & $\begin{array}{l}\text { Pilih tombol hapus di } \\
\text { metode pembayaran } \\
\text { yang akan dihapus }\end{array}$ & $\begin{array}{l}\text { Data metode } \\
\text { pembayaran terhapus }\end{array}$ & $\mathrm{OK}$ \\
\hline 16. & $\begin{array}{l}\text { Konfigurasi } \\
\text { pesanan }\end{array}$ & $\begin{array}{l}\text { Masukkan nilai } \\
\text { konfigurasi yang akan } \\
\text { diubah }\end{array}$ & $\begin{array}{l}\text { Tampil pesan "Data } \\
\text { Berhasil diubah" }\end{array}$ & $\mathrm{OK}$ \\
\hline 17. & Menu logout & Pilih tombol logout & Keluar dari sistem & $\mathrm{OK}$ \\
\hline
\end{tabular}

Pengujian sistem E-Commerce ini setidaknya dilakukan sebanyak 3 (tiga) kali oleh masing-masing tipe pengguna sampai akhirnya seluruh fungsi yang diujikan dapat berjalan tanpa ada gagal sistem. Hal ini dilakukan untuk memastikan bahwa seluruh fungsi yang tersedia berjalan dengan baik.

Pada penelitian ini, iterasi yang dilakukan sampai sistem E-Commerce selesai dan sesuai dengan kebutuhan toko Denia Donuts dilakukan sebanyak 3 kali iterasi. Hasil yang ditampilkan pada penelitian ini merupakan prototype iterasi terakhir yang telah disetujui oleh pemilik toko Denia Donuts. Setiap hasil pada proses pembuatan sistem 
E-Commerce ini ditampilkan secara singkat pada artikel ini untuk mewakili apa yang telah dilakukan.

\section{KESIMPULAN}

Dari penelitian ini menghasilkan sistem E-Commerce yang telah diujicobakan dengan menggunakan metode Black Box Testing dan telah diimplementasikan sesuai dengan spesifikasi kebutuhan pengguna. Sistem E-Commerce ini diimplementasikan berbasis web yang dapat digunakan untuk memasarkan produk secara luas dan memudahkan transaksi yang dilakukan oleh konsumen toko Denia Donuts.

\section{UCAPAN TERIMA KASIH}

Ucapan terima kasih disampaikan kepada Lembaga Penelitian dan Pengabdian Kepada Masyarakat Universitas Islam Negeri Raden Fatah Palembang atas dukungan yang telah diberikan berupa bantuan dana penelitian pada klaster Penelitian Pembinaan/Peningkatan Kapasitas.

\section{DAFTAR RUJUKAN}

Arif, S. N., Wanda, A. P., \& Masudi, A. (2013). Aplikasi Administrasi Perpustakaan Berbasis Web SMK Swasta Brigjend Katamso Medan. Jurnal Ilmiah Saintikom, 12(1), 25-36.

Destiningrum, M., \& Adrian, Q. J. (2017). Sistem Informasi Penjadwalan Dokter Berbasis Web Dengan Menggunakan Framework Codeigniter (Studi Kasus: Rumah Sakit Yukum Medical Centre). Jurnal Teknoinfo, 11(2), 30-37. https://doi.org/10.33365/jti.v11i2.24

Gunawan, C. E., \& Fenando, F. (2018). Pengukuran Keamanan Informasi Menggunakan Indeks Keamanan Informasi (KAMI) Studi Kasus di PUSTIPD UIN Raden Fatah Palembang. JUSIFO Uurnal Sistem Informasi), 4(2), 121-132. https://doi.org/10.19109/JUSIFO.V4I2.4107

Gunawan, C. E., Ramadhan, M., \& Indrawan, I. (2013). Sistem Informasi Seleksi Calon Mahasiswa Berbasis Web Di Sekolah Tinggi Teknik Musi Palembang. Juita, II(4). https://doi.org/10.30595/JUITA.V2I4.823

Haerulah, E., \& Ismiyatih, S. (2017). Aplikasi E-commerce Penjualan Souvenir Pernikahan pada Toko "XYZ." Jurnal Prosisko, 4(1), 43-47. Diambil dari https://ejurnal.lppmunsera.org/index.php/PROSISKO/article/download/146/208

Halim, S., \& Aziz, F. (2018). Rancang Bangun Aplikasi Layanan E-Commerce Tempat Oleh-oleh Wisata Anyer. ProTekInfo, 5(1), 26-34. https://doi.org/10.30656/protekinfo.v5i0.714

Kosasi, S. (2015). Perancangan Sistem E-Commerce Untuk Produk Pembuatan Kue. CSRID (Computer Science Research and Its Development Journal), 7(1), 57. https://doi.org/10.22303/csrid.7.1.2015.57-67

Nilamsari, N. (2014). Memahami Studi Dokumen Dalam Penelitian Kualitatif. Wacana: Jurnal Ilmiah Ilmu Komunikasi, 13(2), 177-181.

Nuraeni, N., \& Astuti, P. (2019). Rancang Bangun Sistem Informasi Penjualan Online (ECommerce) pada Toko Batik Pekalongan dengan Metode Waterfall. Jurnal Teknik Komputer AMIK BSI, 5(2), 197-202. https://doi.org/10.31294/jtk.v4i2

Pranita, M. J., Zulfikar, D. H., \& Gunawan, C. E. (2019). Analisis Kepuasan Pengguna Sistem Keagenan PERISAI Menggunakan End User Computing Satisfaction (Studi Kasus: BPJS Ketenagakerjaan Kantor Cabang Palembang). JUSIFO (Jurnal Sistem Informasi), 5(2), 91-104. https://doi.org/10.19109/jusifo.v5i2.5191 
Pressman, R. S. (2012). Rekayasa Perangkat Lunak Edisi Ke-7. In Software Engineering: A Practitioner's Approach, Seventh Edition (7 ed.). Yogyakarta: Penerbit Andi.

Sugiyono, S. (2019). Metode Penelitian Kuantitatif, Kualitatif, dan R\&D. Bandung: Alfabeta.

Suryono, I., \& Java Creativity. (2014). Toko Online Professional dengan Blogger dan Wordpress. Jakarta: PT Elex Media Komputindo.

Susilo, M., Kurniati, R., \& Kasmawi, K. (2018). Rancang Bangun Website Toko Online Menggunakan Metode Waterfall. InfoTekJar (Jurnal Nasional Informatika dan Teknologi Jaringan), 2(2), 98-105. https://doi.org/10.30743/infotekjar.v2i2.171

Wahyuni, T., \& Puadah, U. (2019). Rancang Bangun Aplikasi Penjualan Online di Rajut.i Handmade. Infotech journal, 5(1), 15-22. 